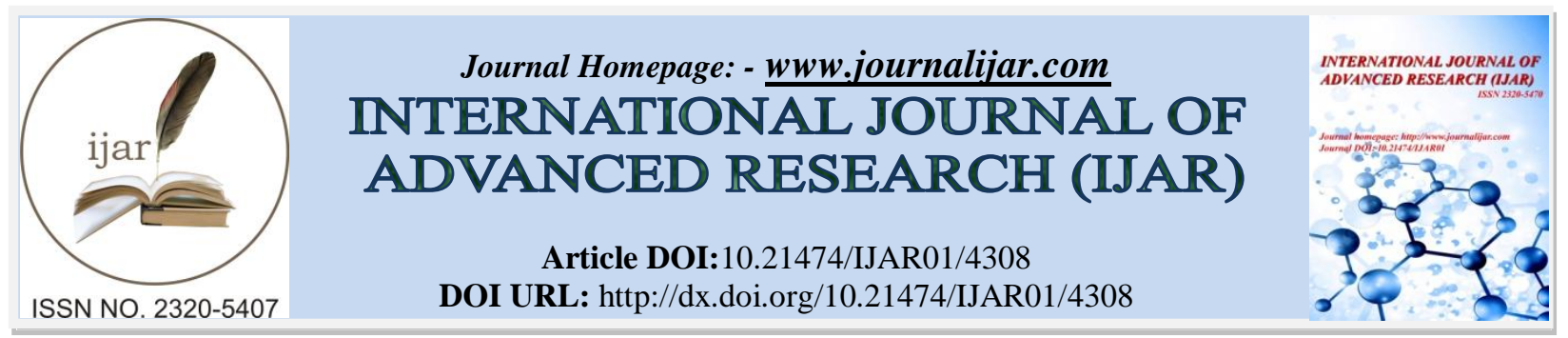

RESEARCH ARTICLE

\title{
PHYTOCHEMICAL VALUATION OF THE UMBELS OF RIDOLFIA SEGETUM (L.) MORIS OF MOROCCO.
}

\section{Jamila EL Karkouri ${ }^{1,2}$, Smail Amalich ${ }^{1,2}$, Aziz Drioiche ${ }^{1,2}$, Kamal Fadili $^{1,2}$, Bruno Eto ${ }^{3}$, Youssef Khabal $^{1}$ and Touriya Zair ${ }^{1,2}$.}

1. Research team of Chemistry Bioactive Molecules and the Environment, University Moulay Ismail, Faculty of Sciences, BP 11201, Zitoune, Meknès, Morocco.

2. Laboratory of Materials Chemistry and Biotechnology of Natural Products, University Moulay Ismail, Faculty of Sciences, B.P. 11201 Zitoune, Meknès, Morocco.

3. Laboratoire Trans Cell Lab, Faculté de Médecine Xavier Bichat 16, rue Henri Huchard, BP 416, 75870 Paris cedex 18

\section{Manuscript Info}

\section{Manuscript History}

Received: 20 March 2017

Final Accepted: 25 April 2017

Published: May 2017

Key words:-

Ridolfia Segetum, Apiaceae, essential oil, Phytochemistry, $C G / S M$.
Abstract

In our study of medicinal plants, as sources of natural bioactive substances, we were specifically interested in the species Ridolfia segétum (L.) Moris harvested in the area of Mchraâ Bel Ksiri Gharb in Morocco during June 2015.

Fresh umbels that have been extracted from the essential oils (HE), by applying the hydrodistillation method, gave an average yield about 2 , $51 \pm 0,05$. The chemical composition of essential oils, determined by gas chromatography coupled with the spectroscopy of mass, shows that the main components of the outcome oil from the fresh umbels are: l' $\alpha$-pinene $(1,18 \%), l^{\prime} \alpha$ - Phellandrene $(6,71 \%)$, p-cymene $(4,91 \%), \%)$, the $\beta$ - Phellandrene $(2.41 \%), \gamma$-terpinene $(8,25 \%)$, paracymene-8-ol $(1,8 \%)$, and the myristicin $(70,27 \%)$.

The identification of the non-volatile chemical families was determined by performing the phytochimical screening on the various extracts of Ridolfia segétum (L.) Moris by colorimetric and/or precipitation tests. The results of the Phytochemical screeningshowed that this species is rich in sterols and triterpenes, in Antraquinones combined genus c-heteroside type, flavonic heterosides and flavonoïde catechols, it contains an average quantity of mucilage as well.

Though, it countains low quantity of alkaloid and is devoid of the leucoanthocyanes, the saponosides, gallic and catechic tannins, oses and holosides and the free antraquinones, the richness of this species in secondary metabolites, particularly in HE, provides high therapeutic effects also explains their use in traditional medicine. Furthermore, a high percentage of myristicin $(70,27 \%)$ certainly makes it an important natural source of this compound.

Copy Right, IJAR, 2017,. All rights reserved. 


\section{Introduction:-}

The aromatic and medicinal plants (AMP) have a major advantage, thanks to the gradual discovery of their essential oils' applications, healthcare, as well as their uses in other domains in economy such as cosmetics, or also agro food industry.

Nowadays, the scientific researches confirm the various virtues of plants and their essential oils, which have a wide range of applications, and are widely used in cosmetics, in the food industry as additives, the perfume shops, the industries of soap as well as detergents and cleaners. They are also included in the composition of several drugs and medicines, in the terms of creams, capsules and suppositories.

Ridolfia Segetum (L.) Moris is a plant from the Apiaceaes family growing spontaneously around the Mediterranean. It bears the same vernacular name of " tebch " as that for the cultivated dill Anethum graveolens (Bellakhdar J. 1997). It is an annual plant of $40-80 \mathrm{~cm}$, glabrous. It is easily recognizable by its tripennatized leaves with filiform, elongated, divaric strips, the upper leaves are reduced to the dilated sheath.

Ridolfia Segetum (L.) Moris is also called the dill of the harvests, it has specific characteristics like notched petals. The fruit flattened perpendicularly in the separation of carpels, while the upper leaves on a sheath are often shorter than the rest of the leaf.

Ridolfia Segetum (L.) Moris is a plant with Mediterranean distribution, extending to Anatolia and Macaronésie, adventitious in Western and central Europe (Thellung, 1926) when it was introduced especially with grains of wheat (Thellung, 1912), But quoted as a woolly weed in Great Britain, France and Germany (Thellung, 1926, Lousley, 1961); it was also found in 1961 on the gravels of the Meuse in the Netherlands, of possible wool origin (Vanoststoom and Reichgelt, 1962). Ridolfia segetum common to Morocco in the harvests especially in the Gharb. It is presented in all Morocco except Sahara, it is plentiful especially on clay soils (Tanji, 2005). In Moroccan folk medicine, the infusion of the plant is used as stomachic, and fruits sprayed of Ridofolia segetum are put in decoct with the madder and the egg. The egg is then eaten in the treatment of the jaundice (Belakhdar J, 1997).

The species has been reported as consumed raw in salads, cooked and medicinal in case of gastric acidity. It is used in medicine to prevent constipation, cough and respiratory tract infections (Lentini and Venza, 2007). It is a plant consumed by the cattle especially before the blooming. These cleaned and peeled stems are consumed (Tanji and al 1995). It regulates women's menstruation and increases milk for lactating women, infusion of the grains helps fight constipation and intestinal gas (Adouane and al on 2015).

The essential oil of Ridofolia segetum has been the main topic of many studies, based on the quantification of the main compounds of essential oils, chemical characterization studies, allowed the distinction of two types of HE; One is largely dominated by monoterpene hydrocarbons such as $\alpha$-phelandrene, terpinolene and p-cymene (Bicchi and al., 2009, Fleisher and Fleisher, 1996, Marongiu and al., 2007, Palá-Paúl and al ., 2002, 2005); And the one which contains phenylpropanoids as main compounds or in large amounts, generally myristicin and dillapiol (Jannet and Mighri, 2007; Jabrane and al., 2010).

Regarding the evaluation of biological activities, Jabrane et al. 2010 evaluated antioxidant and antibacterial activities. In 2007, Jannet and Mighri evaluated the antibacterial properties of the essential oil of R. segetum of Tunisia. Later, in 2009, Bicchi and al. Studied the HIV-1 inhibitory activity of R. segetum in Sardinia of Italy. The last researches which were carried out in 2014 in Portuguese, by J. Pocas and al, figured out that the essential oil of Ridolfia has strong anti-cancer properties specifically aimed at the effect of the viability of human colorectal cancer (RKO) and breast cancer (MCF7).

The main objective of this work is to chemically evaluate Ridolfia segetum (L.) Moris of Morocco by characterizing its essential oils' chemical compositions and performing a phytochemical screening of the secondary metabolites existing in this species. 


\section{Materials and Methods:- \\ Plant Material:-}

Ridolfia segetum (L.) Moris was harvested in the Gharb region of Mechraâ Bel Ksiri. The Gharb plain is located in the north west of Morocco. The plant sample was harvested in June 2015 in its flowering time.

The botanical identification of the species was carried out at the laboratory of Floristics of the Scientific Institute in Rabat. The plant species is found in the spontaneous state. Vegetable matter consisting essentially of umbels at the time of fruiting for hydrodistillation.

Then, they were dried in the shade and finally reduced to fine powder in order to carry out the phytochemical screening.

\section{Phytochemical Screening:-}

The characterization tests of different chemical groups were carried out according to the protocol of DOHOU et al., 2003; JUDITH, 2005; DIALLO, 2005; BEKRO et al., 2007; Bruneton, 2009 and N'Guessan et al. 2009.

The necessary extracts were obtained by extraction with the following solvents: petroleum ether, methanol, ethanol, chloroform and distilled water.

Phytochemical screening was also based on the use of several reagents. The search for alkaloids was carried out by the Dragendorff reagent. The characterization of catechic tannins was carried out by isoamyl alcohol and hydrochloric acid and gallic tannins by the Stiasny reagent, sodium acetate and ferric chloride. For the detection of sterols and triterpenes, acetic anhydride and concentrated sulfuric acid were used. Dilute hydrochloric alcohol, magnesium chips and iso-amyl alcohol were used to search for flavonoids. Chloroform, dilute ammonia and hydrochloric acid have made it possible to investigate quinone substances.

\section{Extraction of Essential Oils:-}

Extraction of the essential oils was carried out by hydro distillation in a Clevenger device. Essential oils recovered from small opaque bottles are stored at $4{ }^{\circ} \mathrm{C}$. The yield of essential oil is evaluated from three extractions of fresh vegetable matter.

\section{Yield Of Essential Oil:-}

The moisture content is calculated after drying three samples of five (5) grams of plant material at $100{ }^{\circ} \mathrm{C}$. in an oven until a constant weight is obtained.

This rate is used to calculate the yield of essential oil. The yield is expressed as a percentage by volume of essential oil (ml) with respect to the mass of the dry plant material $(\mathrm{g})$.

The calculation formulas are the following ones:

$$
\% \mathrm{TH}=\frac{\mathrm{m} 1-\mathrm{m} 2}{\mathrm{~m} 1} * 100
$$

$$
\% \mathrm{R}=\frac{\mathrm{V}}{\mathrm{m}-(\mathrm{m} * \% \mathrm{TH})} \pm \text { ecart }- \text { type }
$$

With:

$\% \mathrm{TH}=$ Percentage of moisture content of the plant material (moisture content).

$\% \mathrm{R}=$ Extraction yield of essential oil expressed as volume of essential oil per mass of plant material $(\mathrm{V} / \mathrm{m})(\mathrm{mean}$ of three yields).

M1 = Initial mass of vegetable matter introduced into the furnace at time (t0).

$\mathrm{M} 2=$ Final mass of vegetable matter in $\mathrm{g}$ removed from the furnace at time (tx).

$\mathrm{M}=$ mass of plant material used for hydrodistillation (in the clevenger).

$\mathrm{V}=$ Volume of essential oil collected (in $\mathrm{mL}$ ).

\pm Standard deviation calculated by the Excel software (Microsoft Office 2007) on the basis of the different yields obtained. 


\section{Analysis and Identification of Eo Components By Gc / Ms:-}

Chromatographiques analyses were carried out on a Hewlett Packard-type gas chromatograph (HP 6890 series), equipped with an HP-5 capillary column (30 mx $0.25 \mathrm{~mm} \times 0.25 \mu \mathrm{m}$ film thickness) An FID detector set at $250{ }^{\circ} \mathrm{C}$ and lined with a mixture of $\mathrm{H} 2$ gas and air. The mode of injection is split, the carrier gas used is nitrogen with a flow rate of $1.7 \mathrm{ml} / \mathrm{min}$. The temperature of the column is programmed at a rate of $4{ }^{\circ} \mathrm{C} . / \mathrm{min}$ of 50 to $200{ }^{\circ} \mathrm{C}$. for 5 min. The device is controlled by an "HP Chemstation" computer system managing the operation of the apparatus and allowing the evolution of the chromatographic analyzes to be monitored. The GC-MS was performed on a Hewlett Packard chromatograph (HP 6890) coupled to a mass spectrometer (HP 5973 series). The fragmentation is carried out by electronic impact at $70 \mathrm{eV}$. The column used is an HP-5SM capillary (30 $\mathrm{mx} 0.25 \mathrm{~mm} \times 0.25 \mu \mathrm{m})$. The temperature of the column is programmed at a rate of $4^{\circ} \mathrm{C}$. / min of 50 to $200^{\circ} \mathrm{C}$. for 5 min. The carrier gas used is helium whose flow rate is set at $1.7 \mathrm{ml} / \mathrm{min}$. The injection mode is split.

The identification of the constituents of the studied HE was carried out both by the method of identification by Kovāts index (1965) and Adams (2007) and from the NIST 2002 mass spectrum data base.

\section{Results and Discussion:- \\ Phytochemical Screening:-}

The results of each characterization reaction of the different chemical groups present in the umbels of Ridolfia segetum are summarized in Table 1.

Table 1:- results of the reactions of characterization of the chemical groups in the umbels of Ridolfia segetum

\begin{tabular}{|c|c|c|}
\hline Chemical groups & Reagents / Reaction & Results \\
\hline Alcaloïdes & $\begin{array}{l}\text { - Dragendorff Reagent: Precipite } \\
\text { - Valse Mayer Reagent: } \\
\text { precipitate }\end{array}$ & $\begin{array}{l}+ \\
+\end{array}$ \\
\hline \begin{tabular}{ll}
\multicolumn{2}{l}{ Tannins } \\
$-\quad$ Galliques \\
$-\quad$ Catéchiques
\end{tabular} & $\begin{array}{l}\text { - Not soluble precipitate in the iso-amyl alcohol } \\
\text { - } \quad \text { Absence of precipitate }\end{array}$ & $\begin{array}{c}+++ \\
- \\
-\end{array}$ \\
\hline \begin{tabular}{ll}
\multicolumn{2}{l}{ Flavonoîdes } \\
- & Anthocyanes \\
- & Heterosidesflavonoïques \\
- & Catechols \\
\end{tabular} & $\begin{array}{ll}- & \text { Of green clear in the most intense } \\
- & \text { Rose cherry } \\
- & \text { Brown red }\end{array}$ & $\begin{array}{c}- \\
+++ \\
++++\end{array}$ \\
\hline $\begin{array}{l}\text { Derives anthraceniques } \\
\text { - Antraquinones libres } \\
\text { - Antraquinones combines : } \\
\text { Genine c-heterosides }\end{array}$ & $\begin{array}{l}\text { - } \quad \text { Yellow persistent } \\
\text { - } \quad \text { More or less intense red }\end{array}$ & + \\
\hline Sterols and triterpenes & - $\quad$ Float green with a brownish red ring & ++++ \\
\hline Oses and holosides & Intense chestnut & - \\
\hline Mucilage & Fluffy precipitate & ++++ \\
\hline
\end{tabular}

The characterization of the saponosides is carried out by determining the height of the foam formed in the tubes, for this species the saponins are entirely absent.

Key to the results of the reactions

- Reaction positively positive: ++++

- Positive feedback: +++

- Medium positive reaction: ++

- Shady reaction: +

- Negative reaction: -

In the case of precipitate, the results were classified as follows:

- Abundant precipitation: +++

- Average precipitation: ++

- Shady precipitate: +

- Negative test: 0 


\section{Interpretation and Discussion:-}

According to the table of results we find that Ridolfia segetum is rich in sterols and triterpenes, Antraquinones combined genus c-heteroside type, flavonic heterosides and flavonoid catechols, as it contains an average amount of mucilage. But it is poor in alkaloid and devoid of leucoanthocyanins, saponosides, gallic and catechic tannins, oses and holosides and free antraquinones. The yellowish flowers of Ridolfia segetum indicate that the umbels are rich in flavonoids. These were the first compounds studied in the genus Anethum. They are present in almost all organs of the plant and play an important role in the defense system as antioxidants. These secondary metabolites are known for their various biological properties: antioxidant, anti-inflammatory, antithrombic, antibacterial, antihepatotoxic, anti-tumor, antihypertensive, antiviral and antiallergic.

\section{Essential oil yield:-}

Three test plugs of $5 \mathrm{~g}$ were introduced into three previously tared boxes. After 24 hours in the oven at a temperature of $103^{\circ} \mathrm{C} . \pm 2{ }^{\circ} \mathrm{C}$. and then cooling in a desiccator, we reweighed again and we determined the new masses of the test samples. Table 3 summarizes the results relative to the yield of the essential oil extracted from the fresh umbels of Ridolfia segetum.

Table3:- Essential oil yield of Ridolfia segetum.

\begin{tabular}{|c|c|c|c|}
\hline Species & Volumes of the essential oil (ml) & TH $(\%)$ & Rdt (\%) \\
\hline Ridolfia segetum & $\mathbf{1 , 6}$ & $\mathbf{3 6 , 2 5}$ & $\mathbf{2 , 5 1 \pm 0 , 0 5}$ \\
\hline
\end{tabular}

- We noticed that the umbels of Ridolfia segetum contain a large quantity of the essential oil, reaches $2.51 \pm$ $0.05 \%$ in $100 \mathrm{~g}$ of plant material.

\section{Chemical Composition of Ridolfia Segetum's Essential Oil:-}

The analysis of the essential oil of Ridolfia segetum by gas chromatography gave a spectrum accentuating two dominant compounds with retention times: 29, 77 and 14, 57 (Figure1). Other compounds in less important percentages are also highlighted by peaks of low amplitude.

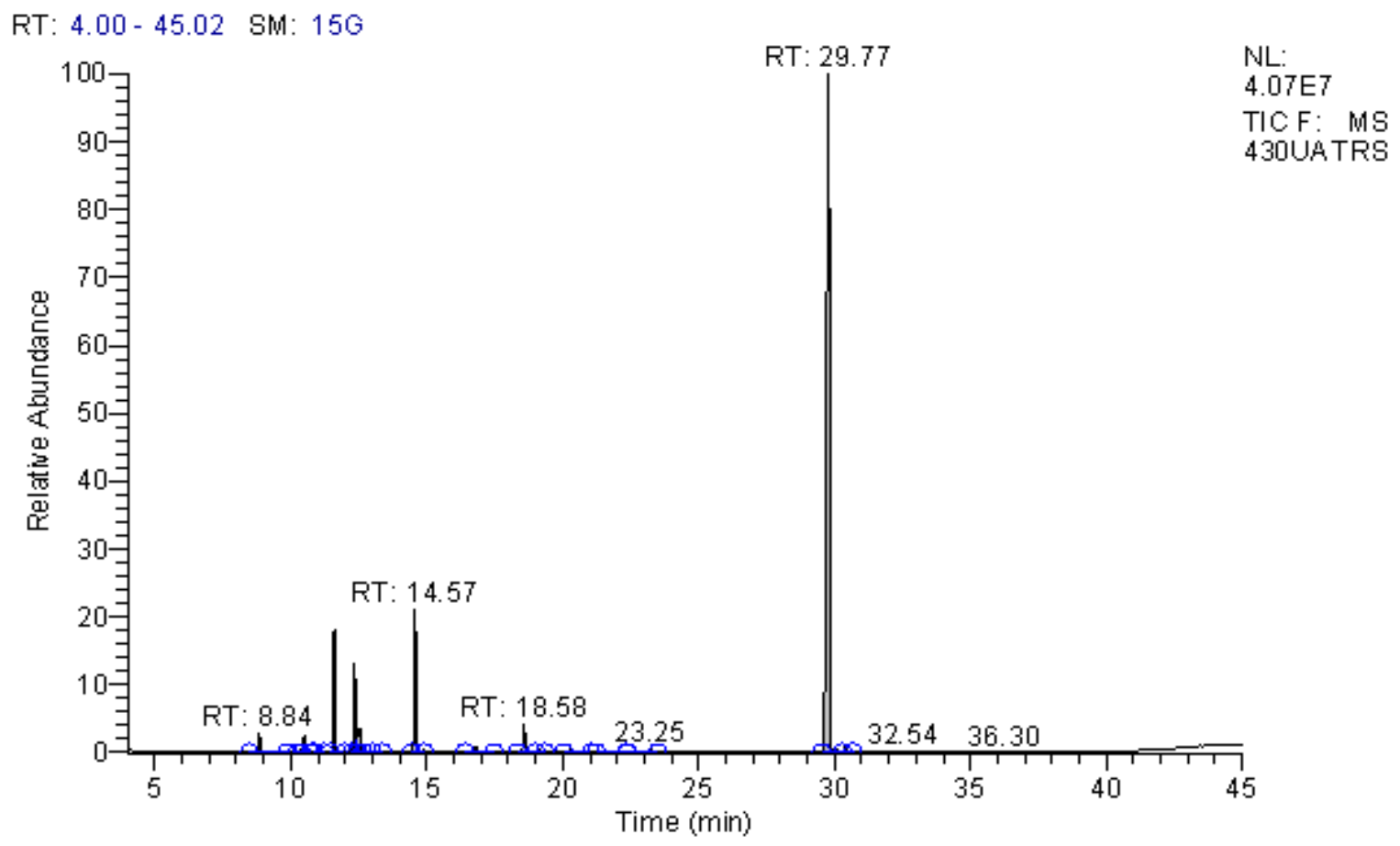

Figure 1:-Chromatogram of Ridolfia segitum essential oil 
The chemical composition of the essential oil of Ridolfia segetum is described in the table 3 .

Table 3:- Chemical composition of the essential oil of Ridolfia segetum

\begin{tabular}{|c|c|c|c|c|}
\hline $\mathbf{N}^{\circ}$ & Compound & Relative abundance (\%) & Formula & IK \\
\hline 1 & $\alpha$-pinene & 1.18 & $\mathrm{C}_{10} \mathrm{H}_{16}$ & 939 \\
\hline 2 & Sabinene & 0.14 & $\mathrm{C}_{10} \mathrm{H}_{16}$ & 975 \\
\hline 3 & $\beta$-pinEne & 0.92 & $\mathrm{C}_{10} \mathrm{H}_{16}$ & 979 \\
\hline 4 & Myrcene & 0.26 & $\mathrm{C}_{10} \mathrm{H}_{16}$ & 990 \\
\hline 5 & $\alpha$-Phellandrene & 6.71 & $\mathrm{C}_{10} \mathrm{H}_{16}$ & 1002 \\
\hline 6 & p-cymene & 4.91 & $\mathrm{C}_{10} \mathrm{H}_{14}$ & 1024 \\
\hline 7 & $\beta$-Phellandrene & 2.41 & $\mathrm{C}_{10} \mathrm{H}_{16}$ & 1029 \\
\hline 8 & Ocimene(Z)- $\beta$ & 0.42 & $\mathrm{C}_{10} \mathrm{H}_{16}$ & 1037 \\
\hline 9 & Ocimene(E)- $\beta$ & 0.14 & $\mathrm{C}_{10} \mathrm{H}_{16}$ & 1050 \\
\hline 10 & $\gamma$-terpinene & 8.25 & $\mathrm{C}_{10} \mathrm{H}_{16}$ & 1059 \\
\hline 11 & Thujone trans & 0.50 & $\mathrm{C}_{10} \mathrm{H}_{16}$ & 1114 \\
\hline 12 & Para-cymene-8-ol & 1.8 & $\mathrm{C}_{10} \mathrm{H}_{14} \mathrm{O}$ & 1182 \\
\hline 13 & Pinocarveol(sis) & 0.36 & $\mathrm{C}_{10} \mathrm{H}_{16} \mathrm{O}$ & 1184 \\
\hline 14 & Dill ether & 0.42 & $\mathrm{C}_{10} \mathrm{H}_{16} \mathrm{O}$ & 1186 \\
\hline 15 & Dihydro carvone cis & 0.23 & $\mathrm{C}_{12} \mathrm{H}_{20} \mathrm{O}_{2}$ & 1192 \\
\hline 16 & Veloutone & 0.41 & $\mathrm{C}_{12} \mathrm{H}_{20} \mathrm{O}$ & 1310 \\
\hline 17 & Myristicin & 70.27 & $\mathrm{C}_{12} \mathrm{H}_{20} \mathrm{O}_{3}$ & 1518 \\
\hline 18 & Elemicin & 0.67 & $\mathrm{C}_{12} \mathrm{H}_{20} \mathrm{O}_{3}$ & 1557 \\
\hline
\end{tabular}

The coupling of gas chromatography with the mass spectrometry (CG / MS) allowed identifying in the essential oil of Ridolfia segetum 18 compounds. All these compounds (100\%) are distributed in monoterpenes $(25,34 \%)$ and monoterpenes mono oxygenated $(3,49 \%)$, monoterpenes trioxygenés $(70,94 \%)$ (Table 4). This essential oil is dominated in $91,73 \%$ by ten compounds compounds whose proportion is greater than $1 \%$. These include : myristicin $(70,27 \%), \gamma$-terpinene $(8,25 \%), \alpha$-Phellandrene $(6,71)$, p-cymène $(4,91 \%), \boldsymbol{\alpha}$-pinène $(1,18 \%), \beta-$ Phellandrene $(2,41 \%)$, and Para-cymene-8-ol $(1,8 \%)$. We notice the presence of myristicin, which is a peculiarity in the chemical composition of the essential oil of Ridolfia segetum both from a qualitative point of view (its presence) rather than a quantitative point of view $(70.27 \%)$.

\section{Main Chemical Compounds of Essential Oil:}

The main chemical families of Ridolfia segetum's essential oil are described in the table 4.

Table 4:- Percentages of the main chemical compounds forming the essential oil of Ridolfia segetum.

\begin{tabular}{|c|c|c|}
\hline $\mathbf{N}^{\circ}$ & classes of compound & \% \\
\hline 1 & Hydrocarbon monoterpenes & $\mathbf{2 5 . 3 4}$ \\
\hline 2 & Oxygenated Monoterpenes & $\mathbf{3 . 4 9}$ \\
\hline 3 & Threeoxygenated Monoterpenes & $\mathbf{7 0 . 9 4}$ \\
\hline 4 & Other & $\mathbf{0 . 2 3}$ \\
\hline
\end{tabular}




\section{Content of different chemical groups $\%$}

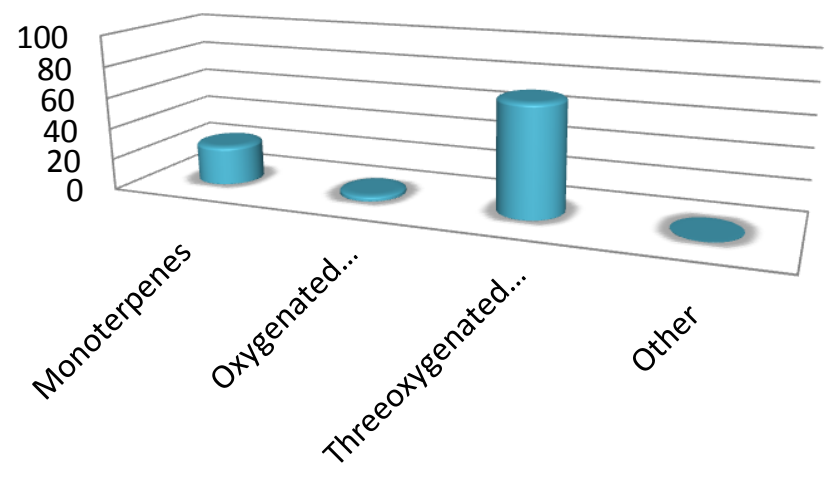

Figure 2:-Histogram of the percentages of the main chemical groupings forms the essential oil of Ridolfia segetum.

Comparison of the chemical composition of Ridolfia Segetum's essential oil according to regions, methods of extraction, used organ:-

We noted certain remarkable differences between our sample and those that are described in the literature, in particular regarding to the quality and the quantity of the most abundant compound and the compounds identified (table 5).

Indeed, the chemical composition of our sample shows similarities with the chemical profile of Ridolfia segetum HE of Italy whose abundance of myristicin, resulting from fruits by hydrodistillation, is of the order of 70, $8 \%$.

This myristicin content varies depending on the crop conditions of the plant, the organ used to extract the HE and the extraction method. It is important to mention the influence of the essential oil's extraction mode on the chemical composition of this oil. For that purpose, Marongiu B and al., 2007, showed the existence of a difference in the chemical composition of HE obtained by hydrodistillation and by extraction with supercritical fluid.

We summarize in the table 5, the main chemical compounds of HEs, of Ridolfia segetum, described in the literature. Table5:- Comparison of the chemical composition of Ridolfia segetum's essential oil according to the harvesting regions, methods of extraction, organs used.

\begin{tabular}{|c|c|c|c|c|}
\hline Region & Methods & organs & Main components & references \\
\hline \multirow[t]{5}{*}{$\begin{array}{l}\text { Spain of the } \\
\text { South }\end{array}$} & \multirow[t]{5}{*}{ hydrodistillation } & Tiges & $\begin{array}{l}\alpha \text {-phellandrene }(39,4 \text { à } 62,0 \%), \text { P-cymene }(10,4 \\
\text { à } 22,7 \%),(Z)-\beta \text {-ocimene }(10.2 \text { à } 11.7 \%) \text { and } \\
\text { Terpinolene }(7.0-15,6 \%),\end{array}$ & \multirow[t]{5}{*}{$\begin{array}{l}\text { Pala-Paúl } \\
\text { and al., } 2002 \\
\text { and } 2005\end{array}$} \\
\hline & & leaves & $\begin{array}{l}\alpha \text {-phellandrene }(61,8 \%-69,5 \%), \quad(Z) \quad-\beta \text { - } \\
\text { ocimene }(10,7 \text { to } 12,0 \%) \text { and Terpinolène }(6,0 \\
\text { to } 10,7 \%) \text {. }\end{array}$ & \\
\hline & & Flower & $\begin{array}{l}\alpha \text {-phellandrene }(44,5 \text { to } 54,7 \%),(Z) \text { - } \beta \text {-ocimene } \\
(08,05 \text { to } 10,06 \%) \text { Terpinolene }(20,1 \text { to } 27,6 \%) \text {. }\end{array}$ & \\
\hline & & Fruits & $\begin{array}{l}\beta \text {-pinene }(01,05 \text { to } 11,09 \%), \alpha \text {-phellandrene } \\
(5,2 \text { to } 56,9 \%), \text { p-cymene }(4,2 \text { to } 25,2 \%), \beta \text { - } \\
\text { phellandrene }(0,9 \text { à } 15,6 \%), \text { terpinolene }(04,03 \\
\text { to } 12,05 \%) \text { and dillapiole }(0,1 \text { to } 45,7 \%) \text {. }\end{array}$ & \\
\hline & & Fruits & $\begin{array}{l}\beta \text {-pinene }(01,05 \text { to } 11,09 \%), \alpha \text {-phellandrene } \\
(5,2 \text { to } 56,9 \%), \quad \mathrm{P} \text {-cymene }(4,2 \text { to } 25,2 \%), \beta \text { - } \\
\text { phellandrene }(0,9 \text { to } 15,6 \%) \text {, Terpinolene } \\
(04,03 \text { to } 12,05 \%) \text { and dillapiole }(0,1 \text { to } \\
45,7 \%) \text {. }\end{array}$ & \\
\hline
\end{tabular}




\begin{tabular}{|c|c|c|c|c|}
\hline \multirow[t]{3}{*}{ Italy } & $\begin{array}{l}\text { The supercritical } \\
\text { extraction of carbon } \\
\text { dioxide }\end{array}$ & Flower & $\begin{array}{l}\alpha \text {-phellandrene }(19,4 \%), \text { Terpinolene }(20,5 \%), \\
\text { piperitenon oxyde }(11,6 \%), \quad \beta \text {-phellandrene } \\
(8,2 \%), \quad(\mathrm{Z})-\beta \text {-ocimene }(7,8 \%), \text { myristicin } \\
(7,5 \%) \text { and } p \text {-cymene }(4,4 \%) \text {. }\end{array}$ & $\begin{array}{l}\text { Marongiu B } \\
\text { and al., } 2007\end{array}$ \\
\hline & \multirow[t]{2}{*}{ hydrodistillation } & Fruits & $\begin{array}{ll}\text { myristicin }(70,8 \%), \text { piperitenone } & \text { oxyde } \\
(19,9 \%) \text { and apiole }(4,2 \%) . & \\
\end{array}$ & \\
\hline & & Flower & $\begin{array}{l}\alpha \text {-phellandrene }(12,9 \%), \text { terpinolene }(11,6 \%), \\
\text { myristicine }(11,0 \%), \quad p \text { - cymene }(9,9 \%), \beta- \\
\text { phellandrene }(8,2 \%) \text { and }(\mathrm{Z})-\beta \text {-ocimene } \\
(6,0 \%) .\end{array}$ & \\
\hline Tunisia & hydrodistillation & Racine & Dillapiole $(47,4 \%)$ and myristicin $(19,2 \%)$ & $\begin{array}{l}\text { Jabrane } \mathrm{A} \\
\text { and al., } 2010\end{array}$ \\
\hline \multirow[t]{2}{*}{ Israel } & \multirow[t]{2}{*}{ hydrodistillation } & Flower & $\begin{array}{l}\alpha \text {-phellandrene }(44,1 \text { à } 48,9 \%) \text {, piperitenone } \\
\text { oxyde }(8,3 \text { à } 18,0 \%) \text { and terpinolène }(11,8 \% \text { - } \\
16,3 \%) \text {. }\end{array}$ & \multirow[t]{2}{*}{$\begin{array}{l}\text { Zhenia } \\
\text { Fleisherand } \\
\text { al., } 2011\end{array}$} \\
\hline & & Leaves & $\begin{array}{l}\alpha \text {-phellandrene }(29,8 \text { to } 37,1 \%) \text {, piperitenone } \\
\text { oxyd }(8,2 \text { to } 14,2 \%) \text { and p-cymene }(8,4 \text { à } \\
15,2 \%) \text {. }\end{array}$ & \\
\hline Portuguese & hydrodistillation & Aerial arts & $\begin{array}{l}\alpha \text {-phellandrene }(53.0-63.3 \%), \quad \text { terpinolene } \\
(11.9-8.6 \%), \quad \beta-\text { phellandrene }(5.5-6.0 \%), \text { and } \\
\text { dillapiol }(1.9-8.0 \%) .\end{array}$ & $\begin{array}{l}\text { C. Cabral } \\
\text { And al., } \\
2014\end{array}$ \\
\hline Algeria & hydrodistillation & grain & $\begin{array}{l}\text { Carvone } 69,9 \% \text {, Apiole } 12.41 \% \text {, limonène } \\
5.62 \% \text {, Dihydrocarvone } 6.6 \% \text {. }\end{array}$ & $\begin{array}{ll}\text { Adamo } & . Y \\
2012 & \end{array}$ \\
\hline
\end{tabular}

The chemical profile of the essential oil of Ridolfia segetum L) Moris varies significantly according to the regions of origin, plant material and extraction process. The chemical compounds that are found in the essential oil are also linked to the stage of development of the species as well as to organs selected for the extraction. And according to the product desired during the exploitation of the species, the selection of organs, vegetative stage and the region, turned out to be very useful to promote the obtaining of the very precise chemotypes.

\section{Conclusion:-}

In our work, we have studied the chemical composition of Ridolfia segetum (L) Morris's essential oil which allowed us to make the following observations:

According to the bibliographical study, the essential oil obviously represents a considerable interest of the fact that they possess an apparent curative potential and have applications in the industrial sector.

The hydrodistillation, chosen method for the extraction of essential oil, has allowed us to show that the Ridolfia segetum L) Moris plant is in fact rich in gasoline.

The extraction of HE by hydrodistillation during three hours, allowed to obtain a yield of 2, $51 \%$.

The results of the qualitative and quantitative analysis of the chemical composition obtained using CG / MS, reveal that the gasoline studied is $70,27 \%$ by aromatic majority compound the miristicin, the results of the phytochemistry shows that the species is rich in sterols and triterpenes, Antraquinones combined genome type c-heterosides, flavonoid heterosides and flavonoid catechols.

These highlighted bioactive molecules also contribute, to the virtues of the plant seen in particular the benefits of polyphenols and flavonoids.

\section{References:-}

1. Adams,R.P.,2004. Identification of Essential Oil Components by Gas Chromatography/Quadrupole Mass Spectroscopy. Allured Publishing Corporation, Carol Stream, IL.

2. Adamo .Y; 2012, Composition chimique et activité biologique del'huile essentielle de l'Aneth : Ridolfia segetum, Mémoire pour obtenir le diplôme de Magister Algérie. 
3. Adouane, S, 2015, Etude ethnobotanique des plantes médicinales dans la région méridionale des Aurès, Mémoire de magistère en sciences agronomiques Algérie.

4. Bekro y.A. et al ; 2007 ; Etude éthnobotanique et screening phytochimique de Caesalpina benthamiana ; Sciences et Natures 4 (2); ed: Herend \& Zarucchi ; p: 217-225.

5. Bellakhdar J. La pharmacopée traditionnelle,Médecine arabe ancienne et savoirs populaires.Paris :Ibis Press ;1997pp 475.

6. Bakkali, F., Averbeck, S., Averbeck, D., Idaomar, M., 2008. Biological effects ofessential oils - a review. Food Chem. Toxicol. 46 (2), 446-475.

7. Bicchi, C., Rubiolo, P., Ballero, M., Sanna, C., Matteodo, M., Esposito, F., Zinzula, L.,Tramontano, E., 2009. HIV-1-inhibiting activity of the essential oil of Ridolfia

8. Bruneton J.,2009. Pharmacognosie, Phytochimie et plantes médicinales. $4{ }^{\text {ème }}$ Edition.Technique et Documentation, 1268p.

9. Cabral, C., Cavaleiro, C., Gonc, alves, M.J., Cruz, M.T., Lopes, M.C., Salgueiro, L., 2013.Otanthus maritimus (L.) Hoffmanns. \& Link as a source of a bioactive and fragrant oil. Ind. Crop Prod. 43, 484-489.

10. Diallo A. ; 2005 ; Etude de la phytochimie et des activités biologique de Syzygium guineense ; Thèse de Doctorat en Pharmacie, Université BAMAKO, MALI ; p: 38-47.

11. Dohou N. et al; 2003 ; Screening Phytochimique d'une Endémique IBÉRO MAROCAINE : Thymelaea lythroides; Bull. Soc. Pharm. Bordeaux 142; p: 61 -78.

12. Kováts E, "Gas chromatographic characterization of organic substances in the retention index system", Advances in Chromatography, vol. 1, pp. 229-247, 1965.

13. Fleisher, Z., Fleisher, A., 1996. Volatiles of leaves and flowers of Ridolfia segetum L. Moris. Aromatic plants of the holy land and the Sinai. Part XII. J. Essent. Oil Res.8 (2), 189-191.

14. Jabrane, A., Jannet, H.B., Mastouri, M., Mighri, Z., Casanova, J., 2010. Chemical composition and in vitro evaluation of antioxidant and antibacterial activities of the root oil of Ridolfia segetum (L.) Moris from Tunisia. Nat. Prod. Res. 24 (6),491-499.

15. Jannet, H.B., Mighri, Z., 2007. Hydrodistillation kinetic and antibacterial effect studies of the flower essential oil from the Tunisian Ridolfia segetum (L.). J.Essent. Oil Res. 19 (3), 258-261.

16. Judith M.D. ; 2005 ; Etude phytochimique et pharmacologique de Cassia nigricans utilisé dans le traitement des dermatoses au TCHAD ; Thèse de doctorat en pharmacie de l'Université de Bamako, Mali ; p: 57- 64.

17. Lentini, F., Venza, F., 2007. Wild food plants of popular use in Sicily. JEE 3, 15.

18. Lousley, J.-E., 1961. - A census list of wool aliens found in Britain, 1946-1960. Proc. Bot.Soc. Brit. Isles 4 : 221-247.

19. Marongiu, B., Piras, A., Porcedda, S., Tuveri, E., Maxia, A., 2007. Comparative analysis of the oil and supercritical CO2 extract of Ridolfia segetum (L.) Moris. Nat. Prod. Res. 21 (5), 412-417.

20. N'Guessan K. et al. 2009. Screening phytochimique de quelques plantes médicinales ivoiriennes utilisées en pays Krobou (Agboville, Côte-d'Ivoire), Sciences et Nature, 6 (1), 1-15.

21. Palá-Paúl, J., Velasco-Negueruela, A., Pérez-Alonso, M.J., Ramos-Vázquez, P., 2002.Volatile constituents of Ridolfia segetum (L.) Moris gathered in Southern Spain,Andalucia Province. J. Essent. Oil Res. 14 (3), 206209.

22. Palá-Paúl, J., Velasco-Negueruela, A., Pérez-Alonso, M.J., Vallejo, M.C.G., 2005.Volatile constituents of Ridolfia segetum (L.) Moris gathered in Central Spain:Castilla la Mancha Province. J. Essent. Oil Res. 17, 119121.

23. Poças,J .,2014.Assessment of the properties of the essential oil from Ridolfia segetum Moris (Portugal) on $\begin{array}{llllllll}\text { cancer cell viability } & \text { Planta } & \text { Med } & \text { 2014; } & 80 & \text { P } & \text { P1L44 }\end{array}$ DOI: $10.1055 / \mathrm{s}-0034-1394701$

24. Tanji A, Nassif F: Edible weeds in Morocco. Weed Technol 1995, 9:617-620.

25. Thellunq, A., 1912. — La flore adventice de Montpellier. Mém. Soc. Nation. Se. Natur.Math. Cherbourg 38 (4e Sér., 8) : 57-728.

26. Thellung, A., 1926a. — DaucusStudkn. Repert. Spec. Nov. Regni Veg. 23 : 147-159.

27. Thellung, A. (coll. HEGI G.), 1926b. - Umbelliferae. In HEGI, G., Illustrierte Flora von Mittel-Europa, München, Lehmans, 5 : 926-1537.

28. Van Ooststroom, S.J. \& Reichgelt, Th.J., 1962. — Adventieven langs de Maas in Limburg III. Natuurhist. Maandbl. 51: 115-116. 